\title{
Investigating journal peer review as scientific object of study: unabridged version - Part II
}

Joanne Gaudet ${ }^{1}$

${ }^{1}$ Department of Sociology, University of Ottawa, Ottawa ON K1N 6N5

\begin{abstract}
AUTHOR'S NOTE: This sociological preprint is Part II of II, an unabridged version of an earlier abridged preprint, "Investigating journal peer review as scientific object of study" (http://hdl.handle.net/10393/31161). The main target audience is natural science and medical researchers, publishers, and policymakers and a secondary audience is social scientists with an interest in natural science and medical journal peer review. This preprint is one of a series in which I explore ignorance (re)production in journal peer review and journal peer review dynamics more generally.
\end{abstract}

(C) 2014 The author (Joanne Gaudet). For any use, the original work must be properly cited: Gaudet, J. 2014. Investigating journal peer review as scientific object of study: unabridged version - Part II. uO Research. Pp. 1-20.

\begin{abstract}
The main goal of this paper is to construct journal peer review as a scientific object of study based on historical research into the shaping of its structural properties. This paper is a second in a two-part series. Journal peer review performed in the natural sciences has been an object of study since at least 1830 . Researchers mostly implicitly frame it as a rational system with expectations of rational decision-making. This in spite of research debunking rationality where journal peer review can yield low inter-rater reliability, be purportedly biased and conservative, and cannot readily detect fraud or misconduct. Furthermore, journal peer review is consistently presented as a process started in 1665 at the first journals and as holding a gatekeeper function for quality science. In contrast, socio-historical research portrays journal peer review as emulating previous social processes regulating what is to be considered as scientific knowledge (or not) (cf., inquisition, censorship) and early learned societies as engaged in peer review with a legal obligation under censorship. However, to date few researchers have sought to investigate journal peer review beyond a pre-constructed process or self-evident object of study. I construct journal peer review as a scientific object of study with key analytical dimensions: structural properties. I use the concept of social form to capture how individuals relate around a particular content. For the social form of 'boundary judgement', content refers to decisions from the judgement of scientific written texts held to account to an overarching knowledge system. Given its roots in censorship with its function of bounding science, I frame journal peer review as following precursor forms of inquisition and censorship. The main implication from insights in the paper is that structural properties in boundary judgement social forms are understood as dynamic when looked at through a historical lens.
\end{abstract}

\section{Introduction}

The main goal of this paper is to construct journal peer review as a scientific object of study based on historical research into the shaping of its structural properties going back to the twelfth century at the start of universities. The paper draws from, and contributes to, historical scholarship on peer review (Gould, 2012, 2013; Rip 1985; Spier, 2002; Gaudet, 2014a) and journal peer review scholarship more generally (Hirschauer, 2010; Zuckerman and Merton, 1973; Biagioli, 2002). The paper is a second of a two-part series, where in the first part (Gaudet, 2014a) I looked more broadly at the historical 
shaping of journal peer review and predecessor forms of inquisition and censorship.

In Gaudet (2014a) I heeded Simmel's proposal to capture the emergence, development, and dissolution of social forms (Levine, 1971:xxvii-xxviii) for scientific exchange and boundary judgement (cf., inquisition, censorship, journal peer review). I also anchored this socio-historical research in existing scholarship and outlined specific knowledge gaps that I intended to address. In this paper, I pursue with Simmel's approach for the study of social forms and focus on structural properties (Levine, 1971:xxvii-xxviii) for boundary judgement social forms of inquisition, censorship, and early journal peer review.

By structural properties of a social form, I refer to elements that contribute to shaping relations in a form around a particular type of content. For boundary judgement, the main content is editorial decisions on whether a manuscript is scientific, or not.

The two main social forms I investigate are scientific exchange and boundary judgement. In principle, the first could be classified as a subtype of the social form of 'exchange' as conceived by Simmel (see economic exchange as subtype of exchange in [1971]1907), and the form of boundary judgement can be classified as having three subtypes. In this work however, I refer to all forms as 'social forms' doing away with hierarchical delineations (see Donati, 2011:13, 178, 181; Medam, 1998).

First, scientific exchange encapsulates relations where scientists communicate scientific knowledge ${ }^{1}$, and more precisely in this work, written communication. Institutionalized relations increased in scientific exchange, for example, when scholars incorporated guilds or universitas starting in the early twelfth century (see Hannam, 2010:74) and later exchanged knowledge institutionally through learned society meetings and journals (see Johns, 2000; Biagioli, 2002).

Second, boundary judgement encapsulates relations where the content of scientific exchange is evaluated against an overarching knowledge system. Before selfregulation in science, the Church held dominant knowledge practices with relations of power over the content of scientific exchange. The three of interest are: inquisition and censorship under mostly religious (with some state/crown) relations of power and journal peer review that eventually mutated to relations of scientific self-regulation.

The underlying argument in the paper is that even though most scholars claim to advance understandings for journal peer review, structural properties for journal peer review as a scientific object of study remain invisible. As elaborated in Gaudet (2014a), I advance that this is mainly because the social, psychological, and philosophical understandings for journal peer review are based on three faulty assumptions. First, that there is only one type of journal peer review (cf., pre-publication journal peer review, aka, traditional peer review). Second, that peer review started in 1665 at the first journals. Finally, that scientific exchange is naturally contingent on traditional peer review. Thus, the main goal in this paper is to construct theoretical structural properties for the social forms of inquisition, censorship, and early journal peer review.

The paper holds three parts. From parts one to three, respectively, I construct theoretical structural properties for inquisition, censorship, and early journal peer review. This includes consideration for relations of accountability (cf., to empiricism, to the reader, to sponsors), social relations (cf., power, economic, and political), and structural

\footnotetext{
${ }^{1}$ Where I refer to scientific knowledge, I include scientific ignorance understood as the limits and the borders of knowledge (Gross, 2010).
} 
dynamics (cf., anonymity for actors, temporality of review, secrecy of review, actors involved). I focus mainly on how and why structural properties are relevant for the social forms of boundary judgement and related meanings given by actors involved. In keeping with Gaudet (2014a), I look to structural properties that differentiate among, and connect, the social forms of boundary judgement (Donati, 2011:178).

Moreover, the structural properties I outline are deceptively descriptive, almost akin to a sociological-historical exercise. Yet, I maintain a steadfast focus on my theoretical proposition that boundary judgement and scientific exchange are not only contemporary, but also historical social forms.

Finally, for each part in the paper (and respective forms), I close with a brief overview of theoretical insights. To conclude, I summarize the main elements from the paper and discuss a core implication.

\section{Structural properties for the social form of inquisition}

Briefly, as outlined in Gaudet (2014a), in the twelfth century the state and the Latin Christian Church increased control over heresy (Hannam, 2010:82; Peters, 1988:40-41) and this included the judgement of written scientific exchange based on religious orthodoxy (cf., the right belief, see Peters, 1988:19, 43). The legal process the Latin Christian Church (and the state) constructed to deal with heresy in the twelfth century was the social form of inquisition (see roots of inquisitional procedure in Roman legal procedures in the first century BC, Peters, 1988:chapter one).

Structural properties changed throughout the form's duration. Initial inquisitional practices during the Middle Ages are sometimes referred to as the Medieval phase. Major changes followed the advent of print and the new social form of censorship (as a function of inquisition, see section below) in the sixteenth century, sometimes referred to as the beginning of inquisition's 'modern' phase (see phases in Tedeschi, 1996:19). The Spanish, Portuguese, Roman, and Italian Inquisitions are a few inquisition institutions (see Peters, 1988; De Bujanda, 1996; Tedeschi, 1996). Changes continued until dissolution when the final remaining Roman Inquisition wielded only limited power within the papal states during the eighteenth century (see Peters, 1988:119). In this section I explore structural elements that pertain to boundary judgement in inquisition for the Medieval phase and for the 'modern' phase. Although a function of inquisition, I explore censorship as a distinct social form in the next section.

\section{The Medieval phase}

From Pope Lucius III's original bull in 1184 (issued with the collaboration of the emperor) until the end of the Middle Ages, actors were mostly tasked by the pope to perform inquisition duties ${ }^{2}$. The pope, the papal court in Rome, the reigning emperor, and lay authorities and institutions overseeing criminal proceedings dominated political, legal, and economic relations in the social form (see Hamilton, 1981; Peters, 1988).

A first and enduring relation of accountability for scholars and inquisitors was to orthodox doctrine. Inquisitors included bishops or archbishops in the early twelfth

\footnotetext{
${ }^{2}$ I do not dwell on the heterogeneity of early practices where the pope did not always hold local jurisdiction. In addition, from the thirteenth to the fifteenth centuries secular tribunals performed inquisition duties in England and France for example (Peters, 1988:74). Later, doctrines and procedures tended to be more standardized across Latin Europe (see Peters, 1988:49, 60).
} 
century, individual inquisitors (mostly trained theologians, preachers, and legal experts, Peters, 1988:60) in the twelfth and part of the thirteenth centuries, and from the thirteenth century onward most were specialist investigators members of Mendicant Orders (cf., Dominicans and Franciscans) (Peters, 1988:54-55). Especially relevant is that at least from the end of the thirteenth century, inquisitors enforcing religious orthodoxy were well-educated, including in science (Hannam, 2010:86-87).

Procedurally, inquisitors visited or oversaw regions where they sought out heretics, tried them, and, if the accused were unwilling to return to the faith, were condemned and handed over to secular authorities for punishment (see Hamilton, 1981; Peters, 1988). Heresy accusations could lead scholars to retract/recant written work (or the destruction of works), to amend work, or not to bring any changes. In one example, "... [natural philosopher] William of Conches shrugged off [heresy] accusations with a few amendments to one of his books" (Hannam, 2010:62; see Thorndike, 1923:58-62). In this case, of Conches asked "... those readers who [had] copies of that treatise to make [the] corrections in it" (Thorndike, 1923:60). Amendment to works therefore entailed retroactively making changes to already existing texts, making the review process 'open' to view by actors external to the boundary judgement social form.

Temporally, this meant that a scholar accused of heresy would already have published the work under review. Structurally, boundary judgement was thus postpublication.

In addition, those in charge of ecclesiastical policy were advised by "...professional personnel [in the formal disciplines of theology and law] trained in the new universities" (Peters, 1988:60-61). These legal advisors helped construct increasingly centralized manuals for inquisitors where justifying concordance with or deviance from legal procedures was paramount (1988:59). Concordance with legal procedure meant upholding non-anonymity for inquisitors who made judgements and who could be held to account for these judgements.

Concordance with legal procedure should have also meant non-anonymity for witnesses even though they might fear retaliation if accusations were not proven 'true' (1988:52, 59). Legal advisors, however, eventually made an exception and did not make witness names public, although these were recorded and shared with inquisitor advisers $(1988: 59,66)$. Shielding witnesses from potential local retaliation was justified emphatically by inquisition manual authors (1988:59). Finally, briefly looking at power as process, anonymity for the role of witness could potentially lead to greater power over the accused without due relations of accountability to accusations, 'true' or 'false'.

Furthermore, with respect to anonymity and structural secrecy, the inquisitor was non-anonymous from the very first activities that launched an investigation. The ensuing inquisitor procedures including boundary judgement, however, were executed in secrecy. In contrast, "...the verdicts and sentences were read aloud in public ceremonies" (Peters, 1988:59) and therefore not secret and contrary to the 'closed' procedures, were 'open' to outside actors. Finally, Medieval phase inquisitor relations increasingly moved to centralized authority in inquisition's 'modern' phase.

\section{The 'modern' phase}

In a 'modern' phase, the Spanish, Portuguese, and Roman Inquisitions are some of the centralized inquisitional institutions that emerged from as early as 1536, lasting 
until the eighteenth century with the Roman Inquisition (see Peters, 1988:67-68; De Bujanda, 1996; Tedeschi, 1996). A significant development in 'modern' phase institutions was the construction of censorship - an explicit form of boundary judgement - in response to the advent of the printing press. I return to the form in the next section.

Before delving into censorship, however, I briefly outline four structural elements of centralized Inquisitions. First, an increase in institutionalized relations. The Spanish Inquisition tribunal for example, with procedures explicitly outlined in a series of guides, included the participation of a large numbers of individuals with "...two inquisitors, an assessor (or legal adviser), a constable, and a fiscal, or prosecutor, with a number of assistants" (Peters, 1988:90) that reported regularly to a centralized body.

Second, the emergence of indexes that consolidated listings of condemned works. In France, for example, "[p]rior to the 1540s, inquisition into preaching and censorship of books had involved ad hoc examination of specific sermons or specific judgements against individual books or authors. In 1543, however, the Faculty [of theology of the University of Paris] [...] circulated for the first time a manuscript list of 65 condemned books" (Farge, 1996:84). Below I explore the use of such indexes by Inquisition institutions.

Third, record-keeping was enhanced and centralized. Documents from the Spanish Inquisition for example are still available to this day (Peters, 1988:93).

Finally, the defendant had an 'informed' voice in the trial. Tedeschi (1996) highlighted that one of the judicial reforms brought on by the Church was to give "...the [heresy] defendant a notarized copy of the entire trial (with the names of the prosecution witnesses deleted) and was given a reasonable period of time to prepare his reply" (1996:21). In addition to the formal properties of the social form discussed above, the potential threat of heresy accusations no doubt shaped self-regulated Medieval and later 'modern' scientific cultural practices.

\section{Accountability and self-regulation}

In a climate of denunciation for heresy, scientific exchange practices (cf., letter sharing and the publication of pamphlets and books) would no doubt implicitly account for potential review, held to account to sacred texts. Furthermore, universities, in an effort to minimize heresy accusations, promoted self-regulation with the Oath of 1272 where "... masters swore they would not deliberately involve theology in their discussions" (Grant, 2004:187). Referring to another type of self-regulation, Hamilton (1981) added that although academic heretics were plentiful in Medieval western society "...most of their speculations were so technical that they did not attract either a popular following or popular animosity, and it was normally left to their fellow theologians to convince them of error and force them to recant" (1981:19). Self-regulation here can be framed as 'informal boundary judgement'. Finally, I offer concluding remarks on structural properties for inquisition before the emergence of the social form of censorship.

\section{Concluding remarks on structural properties for inquisition}

In summary, I advance that core theoretical structural elements for a first boundary judgement social form, inquisition, are the following. Multiple actor roles (cf., author, written work, inquisitor, anonymous witnesses, religious authority (cf., pope), 
secular authority (cf., the state/crown handled punishment)) interact under at least one shared relation of accountability - to religious orthodoxy. Non-anonymous competent reviewers produce a judgement of written work for which these same reviewers are held to account. The author role holds an informed voice in inquisition and can review and reply to heresy accusations. Structurally, boundary judgement in inquisition is postpublication. In addition, structural secrecy shields outside actors from inquisitor procedures (cf., 'closed' procedures), but final verdicts and sentencing details are public (cf., 'open' to actors outside of the process). In addition, already printed texts yielded 'open' review. Finally, indexes with consolidated listings of condemned works do away with having to locate specific judgements against written work. This is in keeping with enhanced centralized record-keeping. The rise of print culture leads to rearrangements of structural properties in boundary judgement, however, leading to a new emerging social form: censorship.

\section{Structural properties for the social form of censorship}

With the advent of printing came the new role of censor, new institutional actor roles with learned societies and other institutions, and new structural properties within the social form of censorship. Once more, the focus here is on the constitution of the new emerging form - its structural properties - and how this corresponds with, or differs from, other boundary judgement social forms. I start with a few definitions.

'Censor' from Latin censere or 'assess' was coined in the mid sixteenth century. Equally pertinent is 'censure' (in 1387, originating from Latin censura - charge, dignité de censeur and jugement and from Christian Latin censura divina-jugement sévère, rigeur) (CNRTL, 2012).

Frequently, scholar actors engaged in censorship as censors (Knight, 1980:27). At the learned societies in London and Paris, for example, members had regular appointments as specialized scientific censors (McClellan, 1985:28; Biagioli, 2002:15).

Moreover, economic and political relations varied widely in the social form. Farge (1996) advanced that "[k]ings and judges feared the effects of divine wrath upon the state if heretics went unchecked [and] held in dread anybody wanting to alter the revealed word of God in the Scriptures or proposing to change beliefs and practices of the Church" (1996:75). In France the University of Paris and Parlement started working together in 1521 to censor works (Farge, 1996:76), although Farge (1996) argued that the French State played the leading role at the time, not the Church or the University (1996:77). Furthermore, “...printers and booksellers, clinging zealously to their status as members of the University, took oaths before the University rector recognizing his jurisdiction to inspect their shop or store, to control the price of books, and to approve their content" (1996:76). Finally, in France, from four censors in 1653 the Crown increased its number of censors to approximately eighty over a century (Hahn, 1971:60). In England, it was around 1530 that the licensing system started under the control of legal mechanisms to prevent printers from publishing without prior approval by Statesanctioned authorities (Johns, 1998:230). As outlined in Gaudet (2014a), the Royal Society obtained the privilege of controlling academic censorship. In Portugal, authors were submitted to triple censorship relations with concurrent Episcopal, civil, and inquisitorial censorship bodies (De Bujanda, 1996:166).

Structurally, the censorship social form included a shift from post- to pre- 
publication boundary judgement. In this shift, scientific publications could be held to relations of accountability to State/Crown prerogatives and sacred texts before and/or after their publication. In the Spanish Inquisition in the seventeenth century criticism of censorship was founded on "...the belief that the censorship functions of the Inquisition were an attack, not exclusively upon doctrinal error, but on the expression of ideas itself" (Peters, 1988:164). The meaning of suppressing the expression of ideas reflects contemporary meanings for the suppression of innovative ideas (Gaudet, 2014b). Postpublication censorship of already-published works still occurred, however, including the censorship of imported books (De Bujanda, 1996:167).

To sustain the shift to pre-publication the Church constructed a series of new legal relations. Already in 1515 the Roman Church had constructed universal legislation that imposed pre-publication censorship. In 1564, the Roman Catholic Church prescribed that pre-publication censorship applies to all written works, including those outside of Rome. Bishops and inquisitors or their delegates were to practice censorship by examining and approving texts before publication (see De Bujanda, 1996:157). Eventually in 1571 Pope Pius V instituted the Roman Catholic Church's main censorship body, the 'Congregation of the Index'. Its purpose was to "...examine books that are to be either proscribed, amended or permitted" (Baart, 1895:114) and to maintain an index of these books.

A detailed account of practices gives insights into structural elements. For example, if an already published denunciated book was brought to the attention of the Congregation's secretary was deemed

\footnotetext{
...deserving of censure, a relator, competent to pass judgment because of his knowledge of the subject treated, shall be chosen; and he shall report in writing his animadversions, noting the pages on which are found each of the points he deems censurable.

"But before his report is referred to the cardinals, We desire that a private meeting of the consultors be held, that judgment may be had on the weight of the animadversions of the relator. A meeting of this kind shall be called once each month, or oftener if advisable, by the secretary of the Congregation; and at it shall be present the master of the Sacred Palace, together with six others of the consultors who are each time to be chosen by the secretary according to the subject matter to be discussed. The secretary himself shall be present and write down the opinions of the consultors, which he will then send to the Congregation of the cardinals with the censure prepared by the relator.

Finally in the general Congregation all shall be observed which was prescribed above for the examination of books by the Congregation of the Holy Office; and as it is the duty of the assessor of the Holy Office to inform the Sovereign Pontiff of the acts of the Congregation, so it will pertain to the secretary of the Congregation of the Index, whenever it judges that a book should be condemned or corrected, to seek the assent of the Sovereign Pontiff, and present a careful relation of all the acts in the matter. (Baart, 1895:116).
}

To contextualize, for the Church, meanings of boundary judgement practices included branding ('separating bad from good books') and protection ('saving the reader from moral injury') (see 1895:113). Protection implied that the text could actively injure - and therefore played an active role in a reader-text relation. This further implied that the reader was not capable of judgement in the relation and required protection.

Relationally, the above passage highlights the involvement of competent equals (peers as relators). Structurally, religious knowledge practices still dominated over science, with books accountable to sacred texts. The process also clearly bares a practice of close textual review ('noting the pages on which are found each of the points he deems 
censurable') where the text was given a central, active role. It is equally pertinent to observe that the 'relator' (cf., referee) had to produce a written report through which he could be held to account for the judgment. In seeking final approval by the Sovereign Pontiff, those involved were further held accountable of their judgement, thus mutual accountability.

An example of post-publication censorship in the 1620 'Index of Prohibited Books' is Copernicus' 1543 De revolutionibus. Censorship replaced the author's original claim, so that "...the passages now treat the earth's motion as a hypothesis, not a reality" (Kusukawa, 2012:92). In this example, three passages of the original text in the book were struck out by hand and the judgement's revised claims were handwritten in the margins (2012:92). Furthermore, censoring practices, like printing practices, were not fixed and therefore censorship of already printed books varied. The corrections for the example above were enforced for approximately sixty percent ${ }^{3}$ of the copies in Italy, but none in Spain and Portugal (2012:91).

The Copernicus example highlights another structural element: the potential for censors to enter into relation and modify a work. De Bujanda (1996) noted that "[1]e travail du censeur ne se limite pas uniquement à biffer certains mots et certains passages. Le censeur est un veritable correcteur qui change des mots et substitute des passages en altérant le sens original du texte qui réflétait la pensée de l'auteur. Le censeur devient jusqu'à un veritable collaborateur" (1996:166). This final structural element for censorship is one that persists in the emergent social form of early journal peer review. Before I deal with structural properties for the new form, however, I offer concluding remarks on censorship.

\section{Concluding remarks on structural properties for censorship}

Core theoretical structural elements that differentiated the censorship function of inquisition from earlier inquisition that did not have a censorship function are the following. First, the possibility of relations of accountability to religious orthodoxy not only post but now also before publication. This gave rise to a new meaning for boundary judgement, that of inhibiting new ideas. Second, the continued involvement of multiple actors in relation with texts dominated by religious and secular state actors but now also including enhanced relations with individual and institutional actors such as censors, universities, learned societies, printers, and booksellers. Third, explicitly outlined practices for censorship held meanings of 'branding' good from bad books, 'constructing' the text as potentially actively dangerous, 'protecting' readers from dangerous texts, presumably owing to their lack of judgement. The last two were already present in inquisition, but were now explicit. Finally, post-publication censorship offered open access to judgements of written claims, as did inquisition for amendments. Prepublication censorship in contrast only yielded access to final censored text. With censorship functions delegated to learned societies, and within a context of piracy of scientific works, emerged the social form of early journal peer review (Gaudet, 2014a). The next section delves into the form's structural properties.

\footnotetext{
${ }^{3}$ This example of partial enforcement of censorship practices presages contemporary peer review dynamics for retracted papers with 'invalid' knowledge (e.g., due to misconduct or to error) that continue to be cited (i.e., Pfeifer et al., 1990; Tatsioni et al., 2007; Fang et al., 2012).
} 


\section{Structural properties for the social form of early journal peer review}

The social form of early journal peer review is central to the understanding contemporary journal peer review. It is therefore not surprising that in this part of the paper I provide more in-depth theoretical construction for the form's structural elements. I start with relations of accountability.

\section{Relations of accountability for institutional and individual actors in the form}

Censorship practices in new learned society institutional settings (distinct from universities) included books and new shorter printed periodicals ('Transactions' in England, Johns, 2000:162). In 1663, book censorship practices already laid out some structural and relational properties where the Royal Society Council resolved that "[n]o book be printed by order of the council, which hath not been perused and considered by two of the council, who shall report, that such book contains nothing but what is suitable to the design and work of the society" (Birch (1756) quoted in Biagioli, 2002:21). Reference to 'suitable to the design and work of the society' implies accountability relations to the Royal Society (in addition to accountability to State prerogatives and sacred texts). Eventually a first form of journal censorship (cf., boundary judgement) is thought to have originated in 1665 in both the French Journal des Sçavans ${ }^{4}$ and the English Philosophical Transactions ${ }^{5}$ (Zuckerman and Merton, 1973:462-463). Early examples of relations of accountability give insights into the form.

Instances of journal censorship, for example, highlight the dynamic interaction among State/Crown and religious accountabilities in science. In England, an early example of text being held back from printing by censorship (with accountability to the Crown) occurred at the third number of Philosophical Transactions (Johns, 2000:167). The Royal Society Committee charged with licensing ${ }^{6}$ (reviewing and giving censorship approval to print) deferred a paper by Sir William Petty until its content (particulars relating to a double-bottomed ship) (Birch, 1756-57:40, 42) could be held to account by the King. In France, the Jesuits purportedly temporarily closed down the weekly Journal des Sçavans after only thirteen issues (until 1666) (i.e., Vickery, 2000:78; Biagioli, 2002:16) (at least partially) holding the journal accountable to sacred texts. To speak of journals as entities already engaging in stable relations, however, can be misleading.

\footnotetext{
${ }^{4}$ Later renamed the Journal des Savants. Guédon (2001:5) and Biagioli (2002:15) warned however that this first French publication was more akin to scientific journalism (novelty) than the English Philosophical Transactions that more closely resembles today's scientific journals. Later at the Académie in France, the journal Mémoires is said to have been more akin to contemporary journals and Transactions.

5 The periodical was licensed from the start by the British Royal Society, but was run as a 'quasi-private' venture by one of the (two) Society's secretaries (Henry Oldenburg was the first, 1665-1677), until 1752. In 1753 The Royal Society's new statutes placed the periodical under the Society's President and Council (The Royal Society, 1912:39-40).

${ }^{6}$ The mandatory nature of censorship was linked with the licensing privilege given by the State/Crown in France and in England. In France for example, "l'Académie était tenue de prononcer sur le mérite des machines et sur les demandes de privilège" (Bertrand, 1869). In England, The Royal Society could "... authorize [the appointed printers and engraver] [...], signed by the President, to print such things (touching or concerning the society) as shall be given [to the printer and engraver] in charge by the President and Council, or any seven or more of [the Royal Society's members] (of whom the President to be one)", The Royal Society, 1912:66-67). Biagioli (2002) argued that the statutory requirement of boundary judgement debunks the contemporary myth that journal peer review is a result of the "...hardwon independence of science from socio-political interests" (2002:14).
} 
Fluctuating relations for the journal - and for early journal peer review

It is important to note that at the time, journals (like books before them) were not self-evident fixed modes of print scientific communication. Journals met several obstacles such as piracy (referred to as usurpation), wide fluctuations in sales, problems with booksellers and printers ${ }^{7}$, and frailty in distribution networks (extensive analysis in Johns, 2000; Barnes, 1936:166). From 1679 to 1683, and again from 1687 to 1691 for example, Philosophical Transactions ceased publication due to multiple economic and political struggles. It is only from 1693 onward that it resumed regular publication to this day. Periodicals envisioned as replacements for Philosophical Transactions (e.g., Collection of Letters and Weekly Memorials) at the time did not survive as alternative modes of journal-type printed scientific knowledge (Johns, 1998:540). Frailty of the format cautions me as a researcher not to assume robustness, permanency, or even distribution of structural properties - of not reifying a 'pre-constructed' object.

What is more, even though Philosophical Transactions was revived in 1693, the editors who replaced Oldenburg (now deceased, who had constructed the journal concept and constructed the editor's role), failed to “... establish a civility of perusal and publication [so that] new discoveries were routinely kept secret and "only communicated to friends"' (Johns, 1998:542; quote within quote is from King, 1776:7). The eventual survival of the journal is proof that "civility of perusal and publication" were eventually re-established, but not without relational tensions.

In the periods of journal non-publication described above, value for scientific knowledge was negotiated in scientific exchange among scholars, with no institutional oversight. The lapse in perusal also provides a glimpse into the emergence of perusal as one of the earliest social forms of journal peer review. A precarious social form, it hinged in great part on the institutionalization of embedded social relations of power. In these relations was interdependence. Authors depended on the journal for securing priority in publication and the journal depended on the authors contributing their papers for the continued existence of the journal (see related social form of exchange and power in Crossley, 2011:115). The breaches in publication in the early years of the journal illustrate the mutual power balance in the author/journal interdependency; without authors, the journal ceased to exist and without the journal, the authors restricted exchange in efforts to retain priority and enjoyed limited breath of publication and readership. The role of editor was critical to maintaining civility in the construction of value for knowledge contingent on journal peer review.

In addition, then new periodicals ${ }^{8}$ competed with alternative forms of exchange. Of these were various methods of transmitting manuscript correspondence and alternative universal languages to communicate natural scientific knowledge (Johns, 2000:164; Strasser, 1994). The presence and success of alternative forms of exchange allowed

\footnotetext{
${ }^{7}$ Printers and booksellers played essential roles in science exchange, but they also held competing interests and accountabilities. Journal editors frequently encountered reluctance from printers to print early journals (see Barnes, 1936:166; Johns, 1998:chapter 7). Furthermore, booksellers “ ... initiated and controlled many learned journals, hired editors, determined policy, took the lion's share of the profits, in certain cases supported a system of state-privileged periodicals, and limited editors in their book choices. Editors were not always free even to name their periodicals" (see Barnes, 1936:166).

${ }^{8}$ See a table of periodicals that covered philosophical, medical, or technical knowledge in Johns (1998:536$537)$.
} 
authors to maintain power over the exchange of their knowledge. In contrast, the dominance of one mode such as journal publication over competing modes of communication could lead to an imbalance in power. In the absence of competing modes of communication, authors would be increasingly dependent on a single mode such as journals where journal peer review would give value to their knowledge. In essence, in this imbalance of power, journals would have "...the upper hand" over authors (see balance of power in relationships in Crossley, 2011:115). Dynamics related to the authenticity of the author-text relation reified a need for shorter texts mediated through institutional relations to register author priority over a text.

\section{Relation of authenticity between author and text - priority and plagiarism}

Here I advance that one of the drivers to create a periodical ${ }^{9}$ from the perspective of the Royal Society - the establishment of a public "register" ${ }^{10}$ to ascertain scientific priority (attributing discoveries to the appropriate scholar) (Guédon, 2001:6; Johns, 1998:475-476, 499, 501-502; Johns, 2000:165) - is critical to understanding boundary judgement today. This did not mean that the Royal Society necessarily endorsed claims made in the content of the journal, but it did proclaim that "[i]ts imprimatur [official printer's seal] was [...] a positive mark of distinction and authenticity, guaranteeing that a publication had been produced under conditions of propriety" (Johns, 1998:494). In addition to ensuring priority 'under conditions of propriety', the journal imparted related meanings of distinction or prestige for the publication itself and for the authors who published in it (see prestige bestowed by publication in the Royal Society's nineteenth century journals in Evans Despeaux, 2011:15).

Ensuring relations of authenticity of the author in the author-text relation was important for actors involved therefore, to ensure priority relations over a text. In the seventeenth century (and earlier), rampant piracy of scientific work had given rise to competing practices of establishing priority (Guédon, 2001:6; Biagioli, 2012). One of these was the use of the cryptographic method (cf., ciphers or anagrams as coded written communication containing at least partial descriptions of the discovery and its attribution to a scholar) (i.e., Johns, 1998:484-487 ;McClellan, 1985:310; Biagioli, 2012; Guédon, 2001:6). With cryptography, individual scholars attempted to hold power over their priority claims by distributing ciphers and anagrams to members of the scientific community via correspondence or by sending them to journal editors for date-stamping (see use of sealed notes in France from 1735 to 1983, Biagioli, 2012:226).

Public priority disputes could arise however in (the frequent) cases where at least two scholars claimed priority. When 'public', these disputes could threaten the need for

\footnotetext{
${ }^{9}$ To complement Gaudet (2014a), Johns (2000) explored three main reasons that made periodicity appealing in the mid-seventeenth century: economic potential with small and recurring printing projects with wider potential distribution, minimal financial damage from rampant piracy given the size of the publication, and the demure (non-ambitious) small paper appeal to gentlemen and scholars who did not wish to appear to overtly value fame-seeking (2000:163-164). The 'standard' form of the written scientific exchange therefore migrated from the book to a journal text.

${ }^{10}$ The journal register for priority was structured as a public counterpart to The Royal Society's noncirculating manuscript register (the Register-books). The secretary also had the charge and custody of the latter which contained priority information for experiments (The Royal Society, 1912:124). There are also accounts of The Royal Society secretary contacting the Journal des Savants to publish a paper in order to establish priority in more than one journal (and with a wider audience) (i.e., McClellan, 1985:310).
} 
outward 'civility' in scientific practices (Guédon, 2001:6; Biagioli, 2012:215; Johns, 1998:501-502; Johns, 2000:165). The editor of Philosophical Transactions extended efforts to shield scientific disputes from the public gaze and to publish editorially modified texts that upheld and regulated civility (Johns, 1998:499). Ensuring author authenticity in the author-text relation intersected with a need to enforce boundaries.

\section{Structural secrecy and boundary-making relations - rising contingency relations and gift-giving relations}

On the one hand, journals met the need for civility in establishing priority, but only following mandatory boundary judgement (cf., censorship) before publication. Here, priority-related practices of civility take on cultural meanings of secrecy and of boundary-making with only those within the editorial readership, and sometimes within the learned society, and science more widely being privy to respective moments in the practices (mostly self-regulation with accountability to the Church and the State). On the other hand, by doing so, journals stripped power from individuals to secure priority ${ }^{11}$ and simultaneously helped manage decentralized knowledge (re)production.

Priority debates are especially pertinent. They are pertinent in that disputes with usurpation were at the centre of how experimental natural philosophy effectively (at least in part) shaped, and was shaped by, the journal format and its peer review practices.

In the mid-seventeenth century for example, the Royal Society encountered critique of exclusion and of plagiarism of unpublished content submitted by a scholar (Johns, 1998:502-503; related in Biagioli, 2012). At the time, practices to establish priority already included secretive rights of 'perusal and consideration' (by the editor and potentially others members) (Johns, 1998:502) that enacted secrecy and boundarymaking between those engaged in science at the Royal Society and those who were not.

Perusal practices for the journal appear to have been borrowed from book gift giving at the Royal Society $(1998: 483,499)$. In then contemporary practices, when the Royal Society received a book as a gift and it wished to politely signal regard for the author and knowledge proposed in the book, it offered an institutional assessment of the book - a perusal (cf., creating an abstract, translating the book, and reporting this at a Society meeting). The referees and institutional readers (those referred or delegated to peruse the book) could not publicize their conclusions about the reading as "...the Society ordered that perusals be kept private", and perusal reports were only to be communicated with the book author (1998:483). Journal perusal practices therefore appeared to mirror book perusal (1998:503) as reciprocal gift, in addition to offering potential anonymity of referees ${ }^{12}$.

Furthermore, texts published in Philosophical Transactions, within a meaning of gift giving, can be framed as the reciprocated acknowledgement gift from the Royal

\footnotetext{
${ }^{11}$ See a contemporary example of Chinese researchers having to negotiate their priority over H7N9 avian flu data even though they had clearly been the first to sequence the data and to publish it in a database. The priority dispute arose over the peer reviewed publication of the data (Butler and Cyranoski, 2013).

${ }^{12}$ It is difficult to pinpoint exactly where referee anonymity with respect to the manuscript author (singleblind peer review) became a widespread cultural practice in journal peer review. When outside referees were used at The Royal Society in the nineteenth century for example, "[t]he referees send in confidential reports, and their names are not disclosed" (Strutt, 1968:168). It would appear that anonymity might have been more widespread from 1832 onward (The Royal Society, 1912:163).
} 
Society ${ }^{13}$ replete with authority, prestige, and value bestowed by the Royal Society. Texts that were not published in contrast, can be framed as rejected gifts. Here, the giver (author) personally bore the rejection for a gift deemed unworthy of reciprocation. ${ }^{14}$

The cultural practice of perusal (for books and for Philosophical Transactions) as one of the earliest social forms of pre-publication journal peer review, registration in the Royal Society's register book ${ }^{15}$, and publication of texts in Philosophical Transactions thus "...provided a corpus of texts and artifacts, the authority of which was founded on the self-evident virtues of a collective of gentlemen" (1998:503). The Royal Society here shaped accountabilities with respect to how experimental natural philosophers could communicate their written experimental accounts in the new journal and secure priority. Hence, the Royal Society established and reinforced the publication of short papers and their perusal as the norm. Papers included minute details of experiments, for example, "...in an attempt to create the impression of that the reader was an absent witness to the events recorded" (Johns, 1998:506).

Moreover, members engaged in scientific activity that did not take part in scientific exchange practices contingent on journal peer review endured peer pressure to do so. This was the case for astronomer John Flamsteed in the mid-seventeenth century, for example (1998:558-559). Flamsteed even contemplated resigning his residency as royal astronomer given "...y impertinences of a croud of visitants" who sought "immature papers and writeings forced forth of my hands \& detained as if I had no interest in them" (Flamsteed cited in Johns, 1998:559). This quote highlights the tension between more private work where Flamsteed could be "Master of my selfe" (1998:559) and the Royal Society that imposed the scientific exchange of short written paper through relations of power over scientific exchange and text ownership.

The Royal Society was thus shaping traditional peer review as the dominant process to construct value for written exchange content while also creating a relation for rights to the knowledge for the Royal Society, once in print. In constructing traditional peer review as dominant and by eliminating or devaluing alternative scientific exchange, the Royal Society was altering the author/journal relationship interdependence where the author gained greater dependence on the journal and traditional peer review. These changes were especially evident with a new accountability to experimentalism.

\footnotetext{
${ }^{13}$ I do not delve extensively in the dynamics of gift exchange. I mostly frame the social dynamics of gift giving on work by Godbout (2007). See also Biagioli (1993) on gift exchange as a way of understanding patronage for Galilei Galileo (1993:36-54) and Simmel ([1971]1907) on exchange.

${ }^{14}$ I advance that the gift exchange meaning for peer review continues to this day in pre-publication journal peer review with high prestige journals reciprocating the gift with highly sought after prestige when published in these journals. Rejected papers, in contrast, are encouraged to seek 'lower status' publications that can reciprocate the lower status gift with a lower status publication prestige.

${ }^{15}$ Following perusal, the Society registered contributions in a 'register' book $(1998: 476,484)$. The register book contained details such as the name of the scholar who had made the 'discovery', the date at which it was 'discovered', and details on the 'discoveries' themselves. The use of register, according to Johns (1998), is based on the model of a Stationers' Company register (official printers). Once adopted by the Society however, "...the social conventions surrounding the sue of this new register were to be very different" (1998:477). Registered items included theories, experiments (successful and failed), observations on objects contributed to the Society, artifacts, inventions, and suggestions for future experiments (1998:485). Registration “... was supposed to attest to the veracity of a report" (1998:485). As such, the Society recognized the worth of contributions and acted as "....arbiter of priority disputes" (1998:484).
} 
New relation of accountability to experimentalism and changing text actor

Consequently, in the transition to experimentalism, the Royal Society held a relation of accountability to the society, to religious texts, and a new relation of accountability to experimentalism (later to empiricism). The author role for its part, held relations of accountability to experimentalism, to the new short paper format, to religious texts, and to respective patronage accountabilities.

Furthermore, plagiarism rendered "... all authorial claims uncertain, it threatened the possibility of that community's cohering at all" (1998:508). The threat was important because the very notion of experimental science was, according to its proponents, one based on collectivity, of bearing witness collectively to experiments, and of sharing knowledge (1998:270). The threat had meaning because it undermined the Royal Society's authority to settle disputes (1998:475).

This set experimental natural philosophy as one where successful experiments were not in and of themselves sufficient, they were successful if they "...led interestingly to further conversation, and thence to further experiments" (1998:470). Conversations entailed relations of scientific exchange with other scholars - and hence could lead to usurpation (cf., plagiarism). Repeated usurpation however, encouraged authors to comply with the Royal Society's new journal format - thereby giving the Royal Society greater power over scientific exchange - where authors submitted shorter papers rather than wait to complete books that were more prone to piracy with longer delays to publication (see example for Robert Boyle in Johns, 1998:505).

This no doubt increased fervour to favour scientific truth, self-regulation, faster publication of shorter written works, and registration of new ideas and plans with the Royal Society. Scholars now mostly engaged in experimental natural philosophy constructed the activities as pertinent. Through new journal epistemic relations, printed work was validated and gained value. The nature of the knowledge relations in peer review judgments at the centre of validation and valuation are worthy of a closer look.

\section{Absolute knowledge in journal peer review judgements}

At this juncture, I delve deeper into the dynamic of texts 'not making unacceptable claims' (Biagioli, 2002:23) as borrowed not only from censorship as Biagioli (2002) proposed, but also from inquisition as I argue. From the 'founding charter of the inquisition' in 1184 for example, the Latin Christian Church condemned "...the "insolence" of heretics and "their attempts to promote falsehood" (Peters, 1988:47). It is thus theoretically relevant that the assumption underlying the existence of unacceptable claims is an accountability to absolute knowledge (cf., religious knowledge in sacred texts). The latter confers quasi-absolute power to editorial judgements.

As discussed above, in post religious accountability journal boundary judgement, the role of editorial readers was disentangled from accountability to absolute religious knowledge. Editorial reader judgements appear to have nonetheless maintained quasiabsolute power owing in great part to structural secrecy and to the apparent naturalness of having one dominant ensemble of knowledge practices. This harks back to the shift of authority from religious Divine Right to Nature (as investigated by science) that suppressed other ways of knowing (Zavarzadeh and Morton, 1991:68) discussed in Gaudet (2014a) (see example of heterogeneous ways of knowing in Laplante, 2014). A closer analysis of the dynamics of absolute knowledge and related structural secrecy and 
anonymity can lead to better understanding for the underlying power and trust dynamics.

$\underline{\text { Structural secrecy, trust, faith, and power relations }}$

To start, Simmel (1906) proposed that reciprocal knowledge of individuals engaged in relation (here through peer review) is a " ...positive condition of social relationships" (1906:448). In anonymous peer review, this positive condition of relation cannot be met. In single-blind peer review, the referee is anonymous to the manuscript's author, but the referee knows the manuscript author's identity. Anonymity, or the lack of knowledge about the referee, would therefore make trust in the anonymous referee role and in his/her judgement in that role impossible ${ }^{16}$ based on Simmel's insights on secrecy (1906:450). Furthermore, the role in which the referee is engaged, once anonymous, is one that can inherently potentially exercise greater power over the manuscript and its author. Finally, structural secrecy for the 'perusal' process meant that those outside of the editorial readers did not know who was engaged in review with the exception of the editor, leading to potential lack of trust.

One exception Simmel proposed however, was faith as another type of confidence where "[t]his condition of faith, in a perfectly pure form, detached from every sort of empirical consideration, probably occurs only within the sphere of religion" (1906:450). I argue that a similar type of faith, obtained by replacing absolute confidence in religion with absolute confidence in science, is another way of understanding peer review anonymous referees with structural secrecy of judgements only communicated between the editor and the author. Lack of knowledge about who is acting in the role of referee in such structural secrecy would therefore lead to trust based on faith in absolute scientific knowledge. Under these structural conditions, any referee judgement would reflect absolute knowledge. In addition, only editorial team members that know the identity of actors in the role of referees could pass further judgement on the value of referee reports. The manuscript author and the wider scientific community and beyond, in contrast, would have to have faith in the referee's judgement based on absolute scientific knowledge and trust in the editorial team members' assessment of the judgement.

What is more, related insights into structural secrecy help frame such absolute knowledge understood within the dynamics of empiricism seeking 'truth', where knowledge is dematerialized and depoliticized (see related discussion in Walker, 2004:137). One of the knowers here, the actor in the role of anonymous referee, can therefore be constructed as offering objective anonymous knowledge in referee judgements, separate from the actor as a knowledge producer. Finally, trust and structural secrecy are a product of, and produce, relations in boundary judgement.

\section{Redefining editorial and review relations}

Collaborative editing of manuscripts became routine around 1700 (1936:157). In the 1750s the Royal Society established "...the role of editorial board cum referee" (Bazerman, 1988:137), where the editorial board handled general policy issues and referees handled individual contribution issues (Zuckerman and Merton, 1973:463, 469;

\footnotetext{
${ }^{16}$ Accounts of peer review rejection frequently highlight personal distrust of the anonymous peer with discourse related to individual bias and lack of relevant knowledge to engage in the role of referee (cf., related research and discussion of individual referee bias in this small selection of papers: Granville, 1830, Mahoney, 1977, Resch et al., 2000, Phillips, 2011, Steinhauser et al., 2012).
} 
Bazerman, 1988:137; Kronick, 1990:1321), taking sole responsibility (and accountability relation) out of the hands of an individual editor.

Moreover, since its original publication, the Royal Society Statute allowed the Committee to "...call in to their assistance [...] any other members of the Royal Society who are knowing and well skilled in any particular branch of Science that shall happen to be the subject-matter of any paper which shall be then to come under their deliberation" (The Royal Society, 1912:162). Designated as 'referee', the Fellows provided a written report (much like a 'relator' for the Congregation of the Index in censorship). The earliest instance of a paper being technically 'referred' is on May 25, 1780, with a second instance recorded in 1831, and the practice of adding new relations with the manuscript and the editor becoming more common at the Royal Society from 1832 onward (1912:162-163).

Interestingly with respect to anonymity of referees from 1832, "[f]or some time the name of the person (or persons) to whom the paper was referred is stated in the Minutes of the Committee of Papers, and in all these cases; [...] the persons in question were members of the Council. Soon, however, the name was omitted, the entry being simply 'referred'. There seems to be no means of ascertaining when 'referees' outside the Council were first had recourse to, or when the practice of written reports first began" (1912:162-163). Heterogeneous journal editorial governance practices using outside referees persist to this day as is evident in Gaudet (2014c).

Change to reviewer anonymity relations does not seem to have rested on legal counsel, however, in contrast to changes with respect to anonymity of witnesses in inquisition that were expressly based on established legal procedure and where exceptions had to be extensively justified (see Peters, 1988:59). What this meant for the anonymity of referees is that an actor in a role that bestows judgement, much like that of inquisitor and relator for censorship, could potentially benefit from a relation of power over a manuscript and its author and hold no explicit accountability for the judgement. As discussed above, the accountability relation for an anonymous referee was (and remains) channelled through faith or through relation with an editor. Finally, I offer concluding remarks on structural properties for the social form of early journal peer review.

\section{Concluding remarks on structural properties for early journal peer review}

A first critical structural shift between censorship and journal peer review is that scientific exchange became fully contingent on the boundary judgement social form of journal peer review, unlike the form of censorship that fostered pre- and some postpublication boundary judgement. Here, shorter 'journal' texts began to dominate exchange relations. In addition, a relation of accountability to experimentalism (and later empiricism) added value to the product of scientific exchange (cf., knowledge) that had meaning for those within science. This can be set in contrast to the seemingly lower valuation potential from relations of accountability to religious texts that were external to scholarly communities. In keeping with inquisition and censorship, competent peers still performed review (now referees), but new social relations in the form included those with learned societies, with editors, with members of an editorial committee, and the new shorter journal written format. A final note on relations deals with power - anonymous referees in this form had the potential of wielding greater power over manuscripts and authors. Next I offer a summary of theoretical insights and concluding remarks. 


\section{Conclusion}

In this paper, I pursued Simmel's approach to investigate social forms and focussed on structural properties. I theoretically framed structural properties for inquisition, censorship, and early journal peer review.

Structurally, a core analogy for the three boundary judgement forms was to judge written claims by holding texts to account to an overarching knowledge system. Accountabilities included those to sacred texts for the Church, to priorities for the State/Crown, and later to empiricism. Judgement involved relations with competent reviewers (cf., inquisitors, relators, referees) that could hold varying levels of accountability to their judgements depending on role anonymity. I advanced that a fundamental relation of accountability under inquisition and in censorship was accountability to absolute religious knowledge. In a way, this conferred quasi-absolute power to the judgement that nonetheless could be held to account as evidenced by close textual readings. In early journal boundary judgement post religious review, the role of referee was disentangled from accountability to absolute religious knowledge yet the referee judgement appears to have nonetheless maintained accountability to absolute scientific knowledge and quasi-absolute power with referee anonymity. Secrecy of boundary judgement practices remained constant for the forms. What is more, practices included (or not) the opportunity for the scholar to defend or negotiate changes to the written work. These practices also yielded open (i.e. public) or closed (i.e., between an author and editorial readers) access to the changes or the judgement. Finally, I veered the focus to how law shaped social form relations. Inquisition and censorship relations were based on and were extensively justified if not based on legal premises whereas selfregulating journal peer review held no legal stance (see Biagioli, 2002:13) and seemed to undergo structural changes (cf., to referee anonymity) with no legal counsel.

The main implication from historical theoretical insights is that structural properties in boundary judgement social forms are understood as dynamic when looked at through a historical lens. Theoretically therefore it is not relations of accountability, social relations, or structural dynamics per se that are relevant for the object of study. Instead, it is an acknowledgement of the changing dynamics of structural properties in social forms - that such properties emerge and can eventually cease to be relevant. Although some of the structural properties explored in the paper were present over several or all variations of forms, many were transient or underwent change over time. One example is the change from post-publication boundary judgement in inquisition, to pre- and post-publication boundary judgement in censorship, and finally to prepublication boundary judgement in early journal peer review.

\section{Acknowledgements}

I thank my doctoral supervisor for comments on a related earlier draft. Please note, however, that the ideas, arguments, and remaining errors in this work are solely mine. Research was supported in part by a Joseph-Armand Bombardier Canada Graduate Scholarship from the Social Sciences and Humanities Research Council of Canada. 


\section{References}

Baart, S.T.L. 1895. The Roman Court: A Treatise on the Cardinals, Roman

Congregations and Tribunals, Legates, Apostolic Vicars, Protonotaries, and Other Prelates of the Holy Roman Church.

http://www.archive.org/details/cu31924029392416. New York: Pustet.

Barnes, S.B. 1936. "The Editing of Early Learned Journals." Osiris 1:155-172.

Bazerman, C. 1988. Shaping Written Knowledge: The Genre and Activity of the Experimental Article in Science. Madison WI: The University of Wisconsin Press.

Bertrand, J. 1869. L'Académie des sciences et les académiciens de 1666 à 1793. Paris: J. Hetzel, Libraire-Éditeur.

Biagioli, M. 1993. Galileo, Courtier: The Practice of Science in the Culture of Absolutism. Chicago: The University of Chicago Press.

—. 2002. "From Book Censorship to Academic Peer Review." Emergences: Journal for the Study of Media \& Composite Cultures 12:11-45.

—. 2012. "From ciphers to confidentiality: secrecy, openness and priority in science." British Society for the History of Science 45:213-233.

Birch, T. (Ed.). 1756-57. The History of the Royal Society of London. Volume II. London: Royal Society of London.

Butler, D. and D. Cyranoski. 2013. "Flu papers spark row over credit for data: Rush to publish on H7N9 avian flu upsets Chinese scientists." Nature News, Retrieved May 1, 2013 (http://www.nature.com/news/flu-papers-spark-row-over-credit-fordata-1.12901).

CNRTL. 2012, "Portail lexical du Centre National de Ressources Textuelles et Lexicales: Censure" Centre National de la Recherche Scientifique (France), Retrieved March 27, 2013 (http://www.cnrtl.fr/lexicographie/censure).

Crossley, N. 2011. Towards Relational Sociology. New York: Routledge.

De Bujanda, J.M. 1996. "L'exercise de la censure de l'Inquisition portugaise au XVIe siècle." in Le contrôle des idées à la renaissance: Actes du colloque de la FISIER tenu à Montréal en septembre 1995, edited by J. M. De Bujanda. Genève: Librairie Droz.

Donati, P. 2011. Relational Sociology: A new paradigm for the social sciences. New York: Routledge.

Evans Despeaux, S. 2011. "Fit to print? Referee reports on mathematics for the nineteenth-century journals of the Royal Society of London." Notes and Records of the Royal Society:1-20. doi:10.1098/rsnr.2010.0066.

Fang, F., R.G. Steen, and A. Casadevall. 2012. "Misconduct accounts for the majority of retracted scientific publications." Proceedings of the National Academy of Sciences of the United States of America 109.

Farge, J.K. 1996. "Early Censorship of Printed Books in Paris: New Perspectives and Insights." Pp. 75-91 in Le contrôle des idées à la renaissance: Actes du colloque de la FISIER tenu à Montréal en septembre 1995, edited by J. M. De Bujanda. Genève: Librairie Droz.

Gaudet, J. 2014a. Investigating journal peer review as scientific object of study: unabridged version - Part I. uO Research. Pp. 1-24. 
—. 2014b. How pre-publication journal peer review (re)produces ignorance at scientific and medical journals: a case study. uO Research. Pp. 1-67. http://hdl.handle.net/10393/31198.

- $2014 \mathrm{c}$. All that glitters is not gold: The shaping of contemporary journal peer review at scientific and medical journals. uO Research. Pp. 1-23. http://hdl.handle.net/10393/31238.

Godbout, J.T. 2007. Ce qui circule entre nous : donner, recevoir, rendre. Paris: SEUIL. Grant, E. 2004. Science \& Religion: 400BC-AD 1550. Baltimore: The Johns Hopkins University Press.

Granville, A.B. 1830. Science Without a Head; or, The Royal Society Dissected. London: T. Ridgway.

Guédon, J.-C. 2001. "In Oldenburg's Long Shadow: Librarians, Research Scientists, Publishers, and the Control of Scientific Publishing." Pp. 1-69. Washington, D.C.: Association of Research Libraries.

Hahn, R. 1971. The Anatomy of a Scientific Institution: The Paris Academy of Sciences, 1666-1803. Berkeley LA: University of California Press.

Hamilton, B. 1981. The Medieval Inquisition. London: Edward Arnold.

Hannam, J. 2010. God's Philosophers: How the Medieval World Laid the Foundations of Modern Science. London: Icon Books.

Johns, A. 1998. The Nature of the Book: Print and Knowledge in the Making. Chicago: The University of Chicago Press.

—. 2000. "Miscellaneous methods: authors, societies and journals in early modern England." British Journal of Historical Sociology 33:159-186.

King, W. 1776. The Original Works of William King. Volume II. Edited by J. Nichols. London: printed for the editor, and sold by N. Conant.

Knight, D. 1980. "The Growth of European Scientific Monography Publishing before 1850." Pp. 23-41 in Development of Scientific Publishing in Europe, Edited by A. J. Meadows. New York: Elsevier Science Publishers.

Kronick, D.A. 1990. "Peer Review in 18th-Century Scientific Journalism." Journal of the American Medical Association 263:1321-1322.

Kusukawa, S. 2012. Picturing the Book of Nature: Image, Text, and Argument in Sixteenth-Century Human Anatomy and Medical Botany. Chicago: The University of Chicago Press.

Laplante, J. 2014. "On Knowing and Not Knowing "Life" in Molecular Biology and Xhosa Healing: Ontologies in the Preclinical Trial of a South African Indigenous Medicine (Muthi)." Anthropology of Consciousness 25:1-31.

Levine, D.N. (Ed.). 1971. Georg Simmel: On Individuality and Social Forms, Selected Writings. Chicago: The University of Chicago Press.

Mahoney, M.J. 1977. "Publication Prejudices: An Experimental Study of Confirmatory Bias in the Peer Review System." Cognitive Therapy and Research 1:161-175.

McClellan, J.E.I. 1985. Science Reorganized: Scientific Societies in The Eighteenth Century. New York: Columbia University Press.

Medam, A. 1998. Le Tourment des formes. Ville LaSalle: Hurtubise.

Peters, E. 1988. Inquisition. New York: The Free Press. 
Pfeifer, M.P., G. L., and M.S. Snodgrass. 1990. "The Continued Use of Retracted, Invalid Scientific Literature." Journal of the American Medical Association 263:14201423.

Phillips, J.S. 2011. "Expert bias in peer review." Current Medical Research \& Opinion 27:2229-2233.

Resch, K.I., E. Ernst, and J. Garrow. 2000. "A randomized controlled study of reviewer bias against an unconventional therapy." J R Soc Med 93:164-167.

Simmel, G. 1906. "The Sociology of Secrecy and of Secret Societies." American Journal of Sociology 11:441-498.

—. [1971]1907. "Exchange." Pp. 43-69 in Georg Simmel: On Individuality and Social Forms, edited by D. N. Levine. Chicago: The University of Chicago Press.

Steinhauser, G., W. Adlassnig, J.A. Risch, S. Anderlini, P. Arguriou, A.Z. Armendariz, W. Bains, and C. Baker. 2012. "Peer review versus boundary judgement and their role in innovation science." Theoretical Medical Bioethics 33:359-376.

Strasser, G.F. 1994. "Closed and open languages: Samuel Hartlib's involvement with cryptology and universal languages." Pp. 151-173 in Samuel Hartlib and Universal Reformation: Studies in intellectual communication, edited by M. Greengrass, M. Leslie, and T. Raylor. New York: Cambridge University Press.

Strutt, R.J. 1968. Life of John William Strutt, Thurd Baron Rayleigh. Second Edition. Madison: The University of Misconsin Press.

Tatsioni, A., N.G. Bonitsis, and J.P.A. Ioannidis. 2007. "Persistence of Contradicted Claims in the Literature." Journal of the American Medical Association 298:25172526.

Tedeschi, J. 1996. "A new perspective on the Roman Inquisition." Pp. 15-30 in Le contrôle des idées à la renaissance, edited by J. M. De Bujanda. Genève: Librairie Droz.

The Royal Society. 1912. The Record of the Royal Society of London. London: Oxford University Press.

Thorndike, L. 1923. A History of Magic and Experimental Science: During the first thirteen centuries of our era, Vol. II. New York: Columbia University Press.

Vickery, B.C. 2000. Scientific Communication in History. Lanham MA: Scarecrow Press.

Walker, K. 2004. "'Double b(1)ind': peer review and the politics of scholarship." Nursing Philosophy 5:135-146.

Zavarzadeh, M.u. and D. Morton. 1991. Theory, (Post)Modernity, Opposition: An "Other" Introduction to Literary and Cultural Theory. Washington: Maisonneuve Press.

Zuckerman, H. and R.K. Merton. 1973. "Institutionalized Patterns of Evaluation in Science." Pp. 460-496 in The Sociology of Science: Theoretical and Empirical Investigations, edited by N. W. Storer. Chicago: The University of Chicago Press. 